\title{
Structural and Mineralogical Characterization of a Fossil Hydrothermal System Located at the Outermost Front of the Southern Apennines Fold-and-Thrust Belt
}

\author{
Paolo Fulignati $\left(\mathbb{D},{ }^{1}\right.$ Fabrizio Agosta $\left(\mathbb{D},{ }^{2}\right.$ Claudia Belviso $\mathbb{D},,^{3,4}$ Giacomo Prosser $\mathbb{D}^{2},^{2}$ \\ Antonio Lettino $\mathbb{D D}^{3,4}$ Angela Vita Petrullo ${ }^{3}{ }^{2}$ and Francesco Cavalcante $\mathbb{D}^{3,4}$ \\ ${ }^{1}$ Dipartimento di Scienze della Terra, Università di Pisa, Pisa 56126, Italy \\ ${ }^{2}$ Dipartimento di Scienze, University of Basilicata, Potenza 85100, Italy \\ ${ }^{3}$ Istituto di Metodologie per l'Analisi Ambientale-CNR, Tito Scalo 85050, Italy \\ ${ }^{4}$ Istituto di Struttura della Materia-CNR, Area di Tito Scalo, PZ 85050, Italy
}

Correspondence should be addressed to Francesco Cavalcante; francesco.cavalcante@imaa.cnr.it

Received 12 November 2018; Accepted 30 January 2019; Published 28 April 2019

Academic Editor: Fabien Magri

Copyright (c) 2019 Paolo Fulignati et al. This is an open access article distributed under the Creative Commons Attribution License, which permits unrestricted use, distribution, and reproduction in any medium, provided the original work is properly cited.

\begin{abstract}
Aiming at investigating the hydrothermal circulation along the eastern flank of the Vulture volcano, along the outermost edge of the southern Apennine fold-and-thrust belt (ftb), we studied the fossil hydrothermal alteration that mineralized a transtensional fault that crosscuts volcanoclastic rocks in the Rapolla area. On the basis of structural, mineralogical, and fluid inclusion data, three main stages of activity of the hydrothermal system are documented. Stage 1 was produced by the circulation of fluids having low-pH conditions $(\mathrm{pH} \approx 3-4)$ and relatively high- $\mathrm{SO}_{4}{ }^{2-}$ activity, as testified by the hydrothermal alteration mainly carried out by the alunite group minerals (particularly jarosite), which is typical of an advanced argillic alteration facies. Hydrothermal fluids were characterized by a high temperature of about $200^{\circ}-210^{\circ} \mathrm{C}$. These hot fluids altered and mineralized the matrices of pyroclastic rocks and sealed both burial-related and fault-related fracture networks. Later hydrothermal circulation (Stage 2) was recorded by opal A-rich veins present both within and outside the fault zone. The fluids responsible of opal A precipitation were characterized by lower temperature conditions, probably lower than $100^{\circ} \mathrm{C}$. Current goethite mineralization takes place along the main slip surfaces of the study high-angle fault zone due to low temperature $\left(<30^{\circ} \mathrm{C}\right)$ underground water circulation. This study highlights that a high-temperature hydrothermal system developed in the past within the transtensional fault zone of the Rapolla area when a high thermal anomaly was present. If we take into account that this area is still affected by a heat flux positive anomaly $\left(90 \mathrm{~mW} / \mathrm{m}^{2}\right)$, we may infer that it has the potentiality to be considered an interesting site for future exploration devoted to the finding of medium-enthalpy geothermal resources at depth.
\end{abstract}

\section{Introduction}

Hydrothermal systems cause the redistribution of both energy and mass in response to circulating $\mathrm{H}_{2} \mathrm{O}$ fluids and form in response to thermal perturbations among which the magma-induced thermal anomalies are the most frequent [1]. A hydrothermal system is comprised of the following components: a heat source, a permeable reservoir in which fluids can flush and trigger an active convective circulation, a recharge system, and an impermeable cover, respectively.
The rocks affected by a hydrothermal fluid circulation undergo to a variety of alteration processes due to the instability of the primary mineralogical assemblages, which tend to reequilibrate by forming new minerals stable under the new conditions [2]. As a consequence, the different alteration mineralogical assemblages are primarily controlled by the physical-chemical conditions of the hydrothermal fluids.

High-temperature geothermal systems are quite common in areas characterized by active extensional tectonic environments [3-5]. In the Central Mediterranean region, a very 
pronounced regional heat flow anomaly $\left(>150 \mathrm{~mW} / \mathrm{m}^{2}\right)$ characterizes both the central and southern sectors of the Tyrrhenian Sea and the thinned and stretched fold-andthrust belt exposed along the Tyrrhenian side of the central and southern Apennines, Italy. There, thinning of the lithosphere due to extensional tectonics is accompanied by igneous processes; large-scale intrusion and extrusion phenomena cause the formation of a positive regional anomaly, which is locally greater than $400 \mathrm{~mW} / \mathrm{m}^{2}[3,6]$. Such a significant positive heat flow anomaly is associated with both active and fossil hydrothermal systems, which localize in the high- and medium-enthalpy geothermal fields of the Tuscany, Latium, and Campania regions of Italy. Some of them, the Larderello and Mt. Amiata geothermal fields, for instance, have been exploited for power production since the beginning of the $20^{\text {th }}$ century.

In contrast, the eastern sector of both central and southern Apennines is made up of several tectonostratigraphic units characterized by low values of heat flux $\left(\sim 30 \mathrm{~mW} / \mathrm{m}^{2}\right)$. There, the estimated temperature varies from ca. $30^{\circ} \mathrm{C}$, at $1000 \mathrm{~m}$ below the earth surface, to ca. $60^{\circ} \mathrm{C}$, at depth of $3000 \mathrm{~m} \mathrm{[6].} \mathrm{As} \mathrm{a} \mathrm{consequence,} \mathrm{the} \mathrm{occurrence} \mathrm{of}$ hydrothermal activity in the eastern portion is rarely reported and just limited to some low-temperature thermal springs. The only significant thermal anomaly localizes in the Vulture area, a Middle-Upper Pleistocene volcano whose last episodes of activity took place about $130 \mathrm{kyr}$ [7], with values of heat flux up to $90 \mathrm{~mW} / \mathrm{m}^{2}$ [6]. In this work, we report for the first time evidences of a fossil hightemperature hydrothermal system located along the eastern flanks of the Vulture volcano. The study site, positioned in the vicinity of the Rapolla village of the Basilicata Region, lies along the outermost edge of the southern Apennines. It provides a unique opportunity to investigate the interplay between shallow-rooted faulting, which was associated with very recent thrusting episodes, and high-temperature hydrothermal fluid circulations. The results might help to improve our understanding of the modalities of fluid migration through the upper crust at the frontal portion of active fold-and-thrust belts, and it might represent a key knowledge for a successful exploration and exploitation of geothermal and mineral resources. In fact, integrated geological, structural, mineralogical, and geochemical investigations of either active or fossil hydrothermal systems could be pivotal for the assessment of the relationship between crustal structures and potential geothermal resources [8-12].

\section{Geological Setting}

The study area is located along the outer front of the southern Apennines fold-and-thrust (ftb), at the western margin of the southernmost part of the Pliocene-Pleistocene in age, Bradano Trough foredeep basin [13]. The southern Apennines $\mathrm{ftb}$ is made up of NE-verging, rootless tectonic nappes of Mesozoic-Tertiary sedimentary successions, which were originally pertaining to the African-Adriatic margin, and synorogenic top-thrust deposits [14-19]. During the Upper Miocene-Early Pliocene times, the entire pile of tectonic nappes overthrusted the Apulian Platform, which was crosscut already by NW-SE to NNW-SSE and minor NESW trending extensional faults associated with Cretaceous tectonics and Plio-Quaternary foreland bulging and foreland basin system development [20-25]. Contractional deformation of the whole southern Apennines orogenic wedge ended during the Early Pleistocene and was followed by uplift and exhumation [26-28]. During the Middle Pleistocene, the alkaline potassic to ultrapotassic Vulture stratovolcano formed at the outermost edge of the southern Apennines $\mathrm{ftb}$ ([7, 29-32] and reference therein; [33]). Activity of the Vulture volcano was likely controlled by a $\mathrm{N} 40^{\circ}-50^{\circ} \mathrm{E}$ trending lithospheric discontinuity, which formed in response of the velocity variations that characterized the subduction-related rollback of the Apulian Platform. In detail, the Vulture volcano is made up of lavas and pyroclastics of tephra-phonolitic, phonofoiditic, and foiditic compositions, whereas melilitites and carbonatites are subordinate. Genesis of the Vulture volcano is still unclear, even though an OIB-type mantle source is inferred [7].

At the peripheral sectors of the Vulture volcano, pre-, syn-, and postvolcanic fluviolacustrine sedimentary deposits of the Pliocene and Pleistocene age crop out. Among these, the Venosa basin is located along the northeastern edge of the Vulture volcano [34], and it includes the fluviolacustrine deposits of the Middle Pleistocene age (Figure 1). High-angle fractures often form orthogonal sets with a varying attitude all around the flanks of the Vulture volcano (Figure 1) and were interpreted as due to local stress fields associated with the Vulture-related bulging [35-37]. However, main WNW-ESE to NW-SE striking fracture sets are documented throughout the whole volcanic edifice (cf. rose diagrams in Figure 1) and quite subparallel to the present regional $\sigma \mathrm{h}_{\max }$ of southern Italy [38].

The stratigraphic setting of the eastern Vulture area is reported by Petrullo et al. [24], who documented pronounced lateral variations of the Cenozoic mixed carbonate-terrigeneous formations topping the Mesozoic carbonates of the Apulian Platform. Such a geological setting was interpreted as due to Eocene-to-Miocene in age, strike-slip, and extensional tectonics, which caused the formation of NW-SE, N-S, and NE-SW striking high-angle fault sets. The tectonic setting of the study area was inferred from well logs and seismic profiles downloaded from the VIDEPI website (Figures 2 and 3). Well data were reinterpreted adopting a consistent stratigraphic scheme based on fossil content and lithology. The original seismic profiles, downloaded from the VIDEPI website in raster format, were also reinterpreted and then converted into SEGY files, imported into the Move ${ }^{\mathrm{TM}}$ software, and then digitized (cf. [24]).

Focusing on the Plio-Quaternary tectonic evolution of the eastern Vulture area, NE-verging thrusting of a tertiary allochthonous complex on the topmost infill of the Bradano Trough occurred by means of a sole thrust that localized on top of the Pliocene clay units (Figure 2(b)). Low-angle splay thrust faults departing form this sole thrust were documented by Sinisi et al. [37]. The allochthonous complex was not profoundly affected by the latest stages of activity of the NW-SE high-angle faults (Figure 2(b)), whereas both 


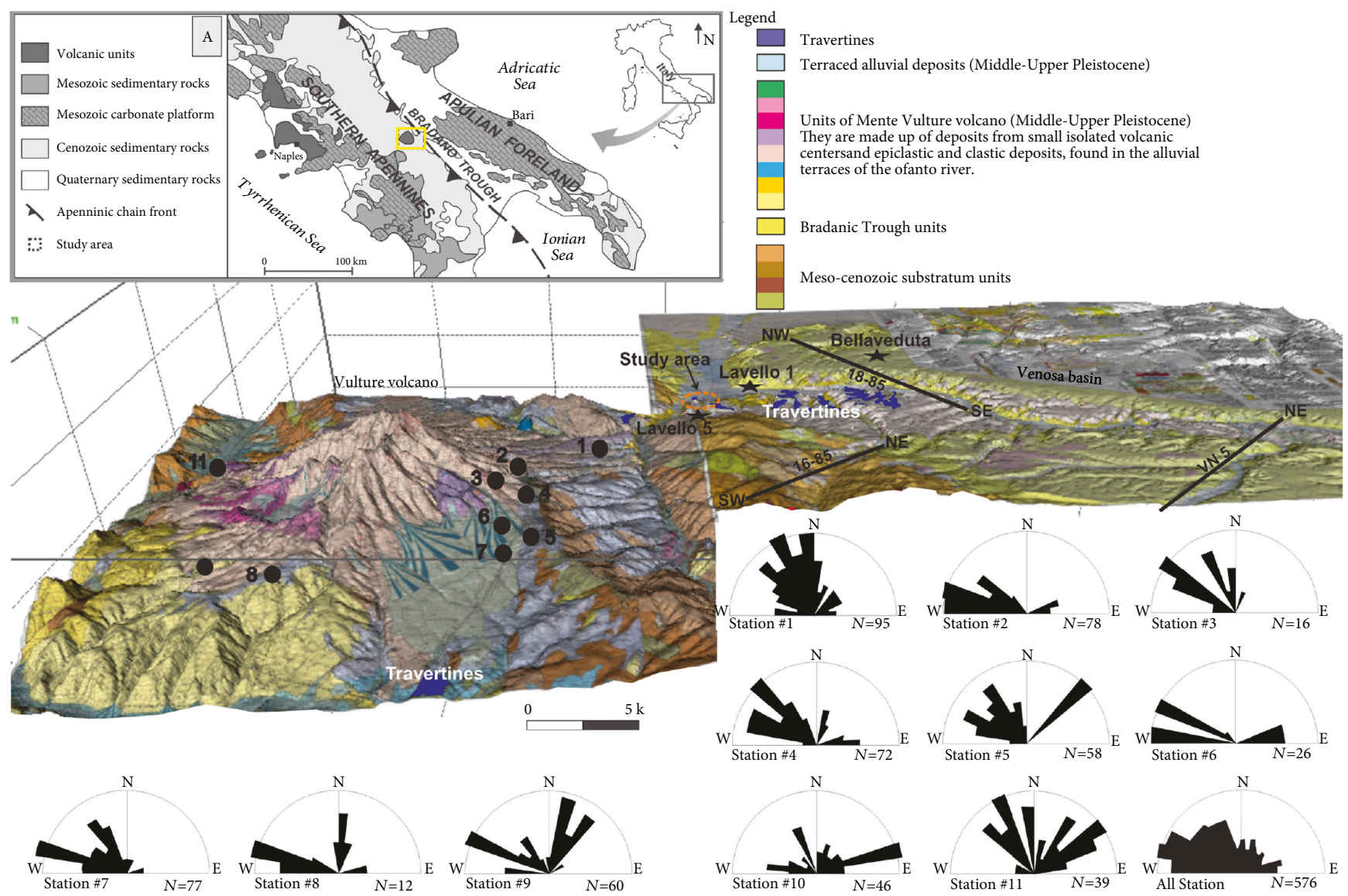

Figure 1: 3D geological map, constructed using Move ${ }^{\mathrm{TM}}$ software, of the Vulture volcano area (modified after [54]). Location of measurement stations (\# 1 to 11) and rose diagrams (bin size $10^{\circ}$, the outer circle corresponds to the $20 \%$ of cumulative data) of the high-angle fractures crosscutting the fluviolacustrine deposits and volcanic rocks are reported (modified after [36]). The Lavello 5, Lavello 1, and Bellaveduta wells and the 16-85, VN 5, and 18-85 seismic lines are located in the map.

NE-SW and N-S fault sets were mainly active prior to the formation of the Bradano Trough (Figure 2(c)). The eastward lateral termination of the allochthonous complex is nicely shown by the well log correlation reported in Figure 3.

\section{Sampling and Methods}

Selected key outcrops were studied in detail by means of integrated field and laboratory analyses. The field survey was aimed at deciphering the geological setting and fault architecture exposed along the artificial outcrops of the Toppo D'Aguzzo Quarry, which occurs in the vicinity of the Rapolla village of Basilicata (Italy). In particular, field structural analyses focused on the nature, distribution, and relative timing of the formation of the structural elements exposed along the walls and pavements of the aforementioned quarry.

To determine the mineralogical composition of veins and pipe fluid conduit infill, 44 samples were collected at 3 different stations (cf. Figure 4) and then analyzed by X-ray diffraction (XRD) analysis using a Rigaku Miniflex powder diffractometer equipped with a sample spinner, with $\mathrm{Cu}-\mathrm{K} \alpha$ radiation, $30 \mathrm{kV}$, and $15 \mathrm{~mA}$. Since most of the samples showed a zonation with different colors, each of them was investigated to define the order and the evolution of the different mineral phases over time. With this aim, selected samples were also analyzed by optical microscopy (OM) using an optical polarizing microscope. Scanning electron microscopy (SEM) investigation was also performed using a PHILIPS XL30 ESEM operating at a beam current of $1 \mu \mathrm{A}$ and an accelerating voltage of $15 \mathrm{kV}$.

Doubly polished thin sections (100-300 $\mu \mathrm{m}$ thick) were prepared for petrography and microthermometric determinations of fluid inclusions. Measurements on fluid inclusions were made using a Linkam THMS 600 heating-freezing stage. The accuracy of measurements is estimated at $\pm 2^{\circ} \mathrm{C}$ at $398^{\circ} \mathrm{C}$ controlled by the melting point of $\mathrm{K}_{2} \mathrm{Cr}_{2} \mathrm{O}_{7}$ and $\pm 0.1^{\circ} \mathrm{C}$ at $0^{\circ} \mathrm{C}$ and $\pm 0.2^{\circ} \mathrm{C}$ at $-56.6^{\circ} \mathrm{C}$ controlled by using certified pure water and $\mathrm{CO}_{2}$-bearing synthetic fluid inclusions (Synthetic Fluid Inclusion Reference Set, Bubbles Inc., USA).

\section{Results}

4.1. Geological and Structural Analyses. In the Rapolla area, the structural grain is provided by NE-SW high-angle faults (Figure 4). The NE-striking faults crosscut both gravel and coeval tuff deposits and were interpreted as tear faults of the NE-verging splay thrust faults displacing the allochthonous complex on the foredeep deposits [37]. The NE-SW 


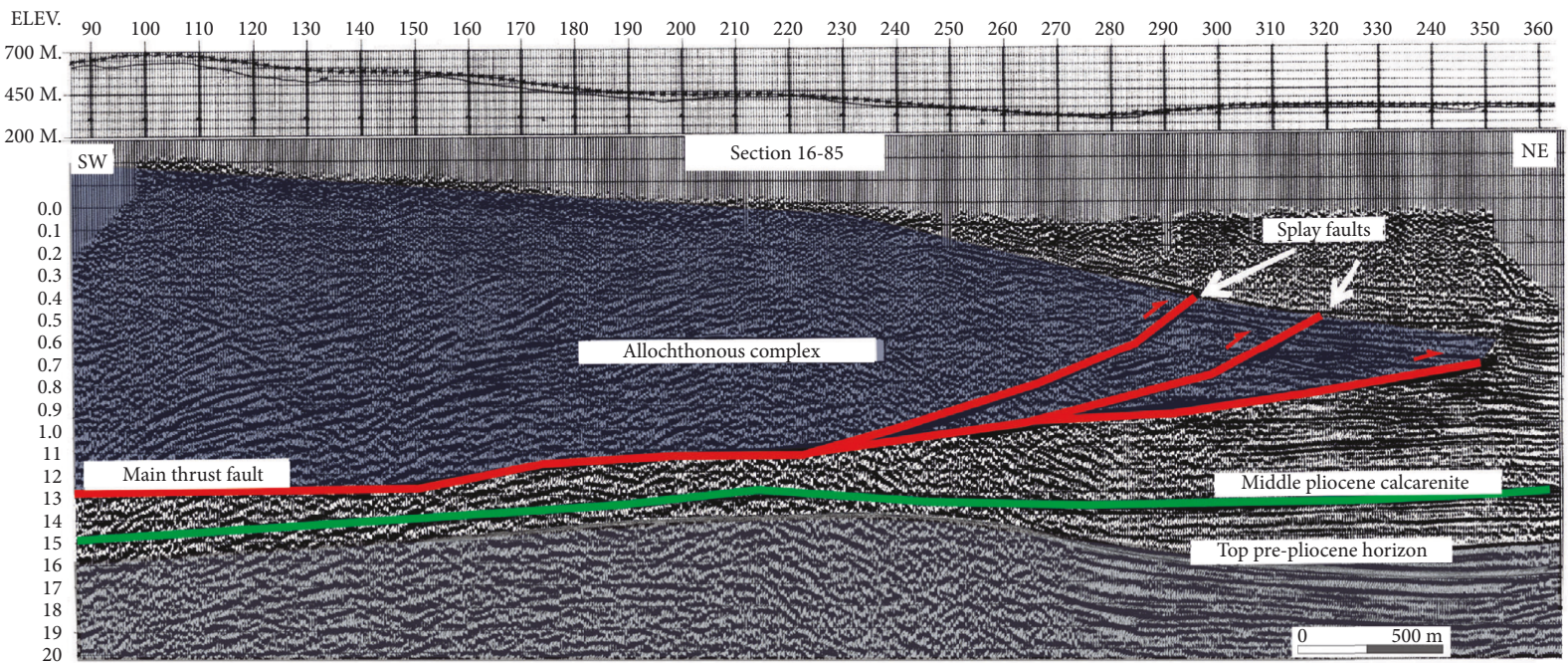

(a)

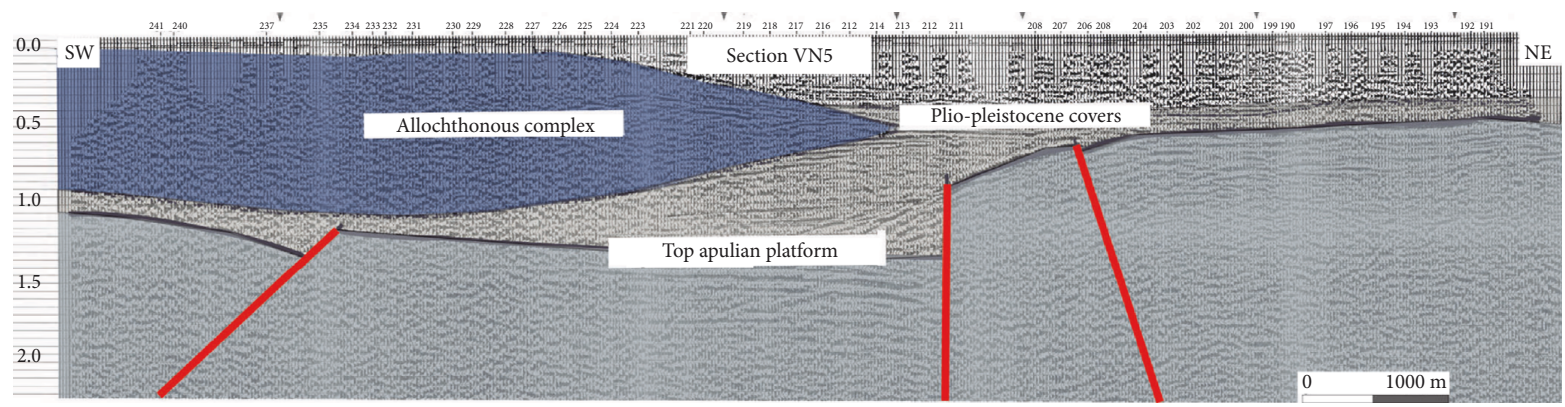

(b)

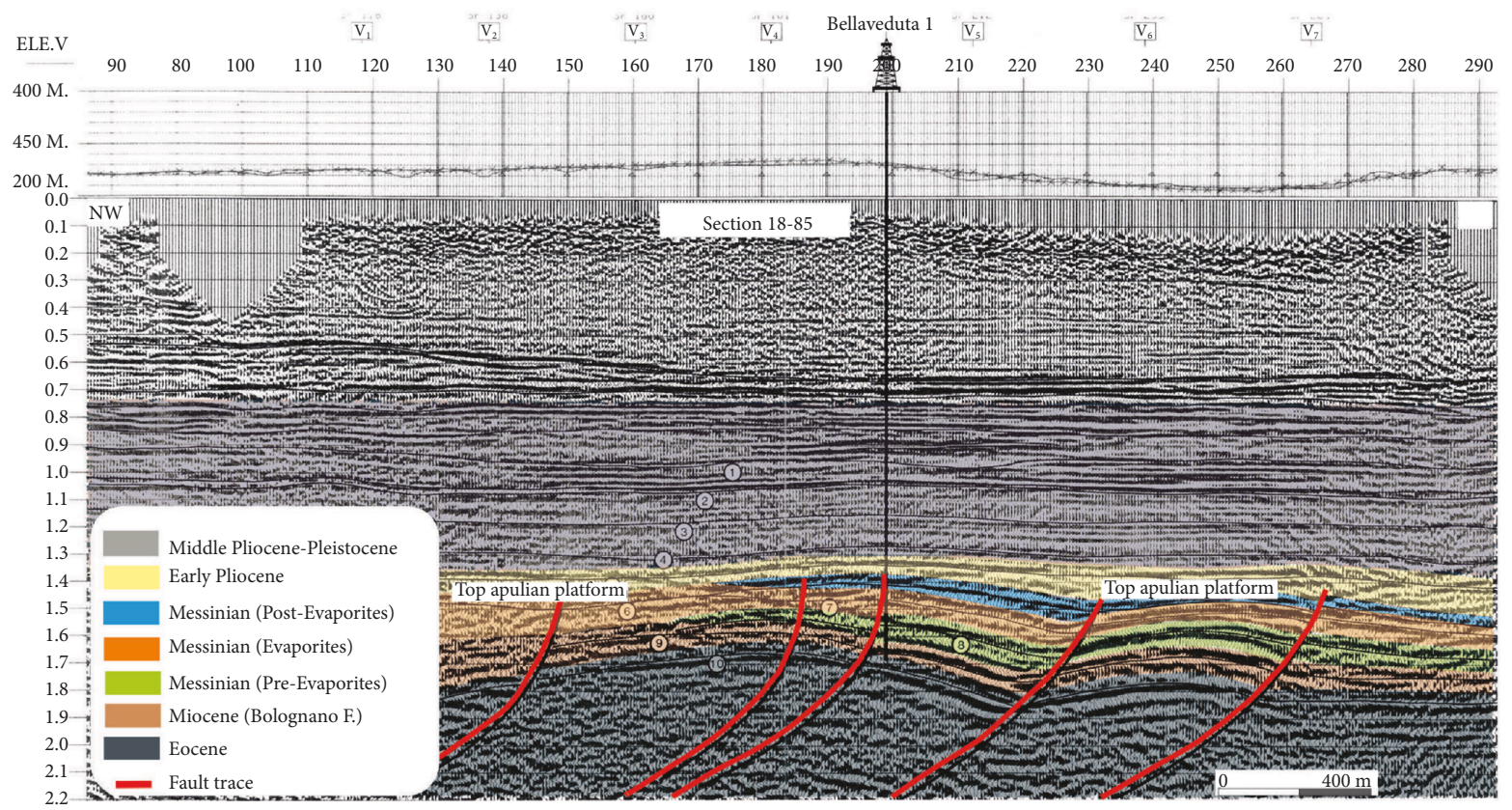

(c)

FIgURE 2: (a) Interpreted NE-SW-oriented seismic reflection profiles 16-85 in which the main decollement and the splay thrust faults displacing the Pleistocene sedimentary succession are highlighted; (b) interpreted NE-SW-oriented seismic reflection profiles VN5 across the south-eastern sector of the study area, showing the allochthonous complex overlying the Plio-Pleistocene covers and NW-SE-directed faults displacing the Apulian Platform; (c) interpreted NW-SE-oriented seismic 18-85 across the north-western sector of the study area, showing the listric geometry of the N-S-directed fault zone that displaces gently folded Eocene-Miocene succession. See Figure 1 for location. 


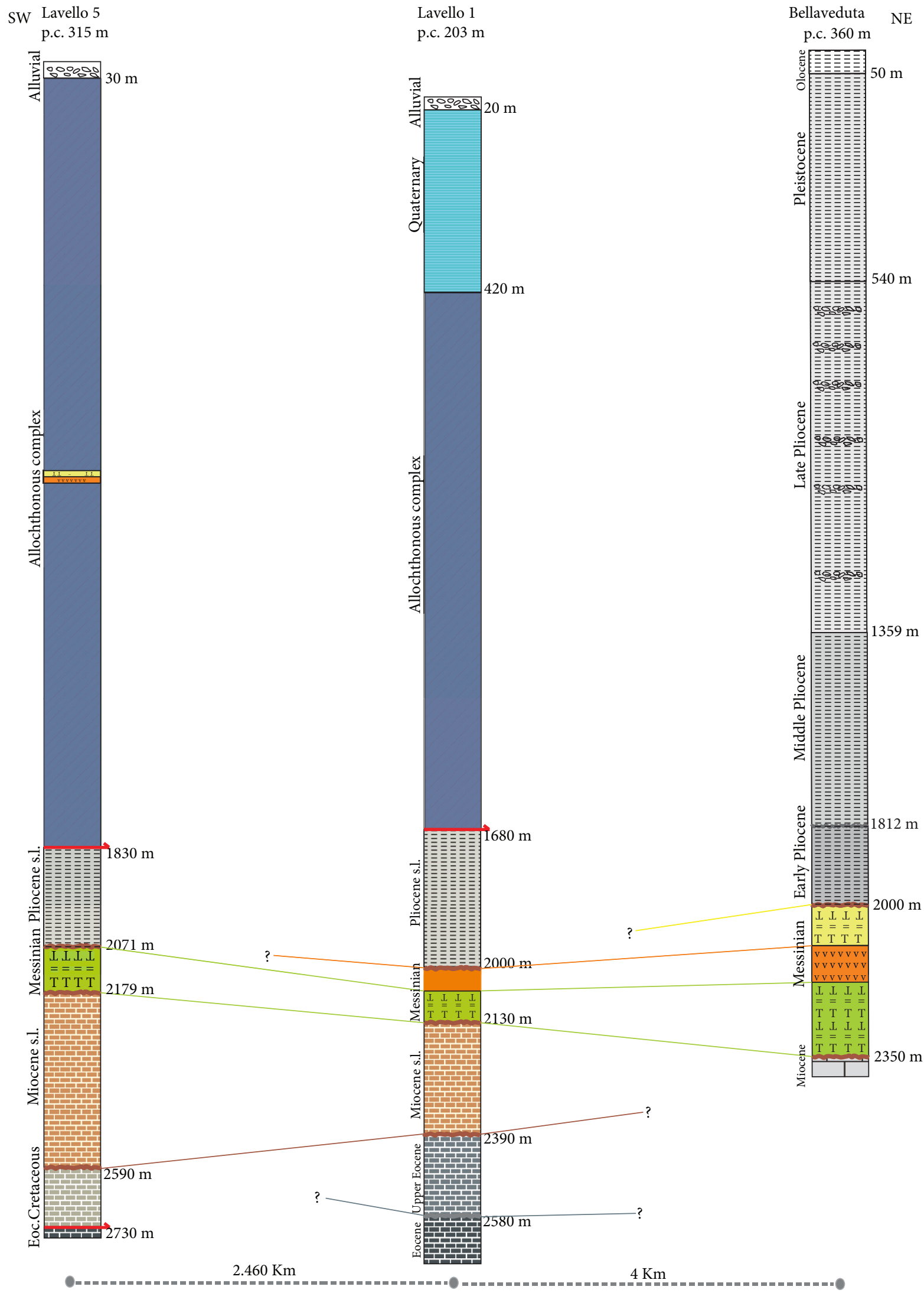

FIGURE 3: Schematic stratigraphic profile, NW-SE oriented, derived from the correlation of Lavello 5, Lavello 1, and Bellaveduta exploration wells. See Figure 1 for the location of the wells. 


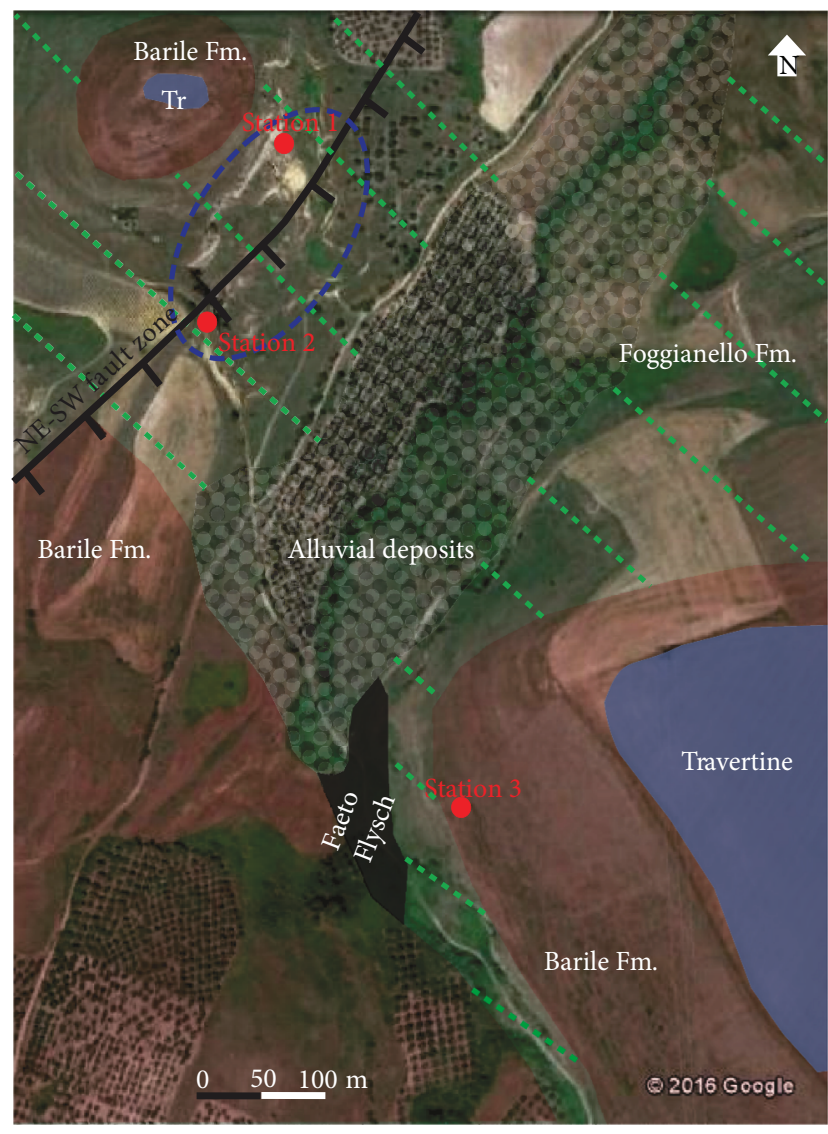

Legend

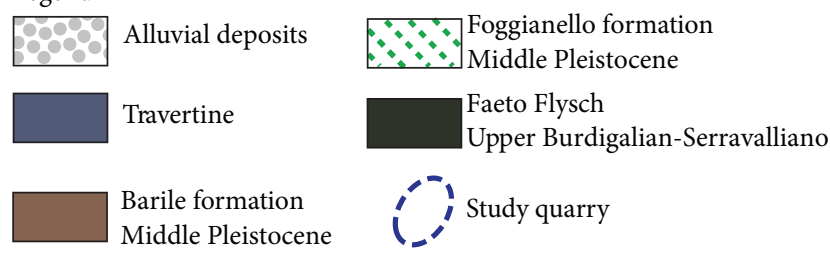

FIgURE 4: Geological map based on Google earth image of the Rapolla area, in which the location of the sampling sites and the investigated outcrops for structural analysis are reported.

trending, SE dipping normal fault zone exposed at the Toppo D'Aguzzo Quarry in the vicinity of the Rapolla village of Basilicata, is characterized by an average throw of $25 \mathrm{~m}$. It includes multiple slip surfaces coated with kinematic markers such as calcite fibers, calcite steps, and abrasive striae, which are all consistent with pure extensional kinematics. The fault core, as thick as several $\mathrm{cm}$, consists of grain- and matrix-supported poorly cohesive cataclasites and major slip surfaces (Figure 5(a)). Many subsidiary synthetic and antithetic slip surfaces localize in the vicinity of the fault core (inset of Figure 5(a)). Away from the main slip surfaces, the weakly fractured footwall fault damage zone is crosscut by N-S and NE-SW striking, subvertical veins (Figure 5(b)), and minor E-W veins (Figure 5(c)). Subsidiary NE-SW normal faults are also present throughout the whole footwall fault damage zone and are characterized by small vertical fractures that mainly localize at their mode-II extensional quadrants (Figure 5(d)). Such a structural architecture is hence consistent with predominant opening-mode mechanisms and dilation of the whole high angle, NE-SW trending fault zone (cf. [37]), similar to other normal fault zones in carbonates $[39,40]$ and siliciclastic rocks [41]. Late NW-SE joints abutting all the aforementioned fracture sets are also documented within the footwall fault damage zone (Figure 5(e)).

4.2. Mineralogical and Petrographic Analyses. The mineralogical analyses were performed only on the samples collected from site 1 to 3 represented by pyroclastics of the Foggianello and Barile synthems, respectively, within and outside the study NE-SW trending, high-angle fault zone. Figure 6 shows the OM and SEM images and the XRD patterns of a representative sample collected from site 3 (cf. Figure 4), within the volcaniclastic rocks of the Barile synthem. In detail, a dark host rock (Figure 6(a)) reveals the presence of abundant clinopyroxene and feldspars (plagioclase and k-feldspars) by means of optical microscopy analysis (Figure 6(b)). This host rock is crosscut by a $1 \mathrm{~cm}$ thick, whitish, N-S trending silicarich vein that includes some lithic fragments derived from the flanking microconglomerates (Figure 6(c)). SEM and EDX data (Figure 6(d)) support the aforementioned interpretation. XRD data performed on the dark host rock also indicates the presence of micas, pyroxene, and feldspars, whereas the whitish vein is almost exclusively made up of opal A (Figure 6(e)).

A representative hand specimen collected from site 1 (cf. Figure 4) is shown in Figure 7. There, the weakly fractured yellowish host rock, which pertains to the Foggianello synthem, is crosscut by a whitish NE-SW trending vein (Figure 7(a)). Optical microscopy analyses are consistent with the presence of quartz, feldspars, and strongly altered phenocrysts of pyroxenes in the host rock (Figure 7(b)). Results of SEM analyses point out to crystals of quartz characterized by a rim of pervasive jarosite and opal, which are dominant in the whitish vein (Figure 7(c)). Goethite is also present along the vein margin. X-ray profiles confirm that host rock is characterized by both jarosite and quartz minerals besides a large amount of opal A (Figure 7(d)).

Figure 8 (a) displays a representative hand specimen collected from site 2 (cf. Figure 4), within the highly fractured pyroclastic rocks of the fault damage zone, pertaining to the Foggianello synthem. Results of optical microscopy analysis indicate the presence of quartz, feldspars, and rare clinopyroxenes in the host rock. The brown veins, ca. NE-SW trending, are characterized by iron oxide-hydroxide (Figure 8(b)), which is consistent with the presence of goethite within the host rock, together with both jarosite and opal A (Figure $8(\mathrm{c})$ ). Isolated feldspar grains are also identified within the host rock. In detail, the SEM image (Figure 8(d)) shows a crystal of quartz with a rim of jarosite (EDX spectrum) and pervasive opal A. XRD performed on both host rocks and veins confirms the aforementioned results (Figure 8(e)). In fact, X-ray patterns of the host rock delineate of a large amount of jarosite and, subordinately quartz. The veins show a broad band from 15 to $32^{\circ} 2 \theta$ indicating the presence of opal A. 


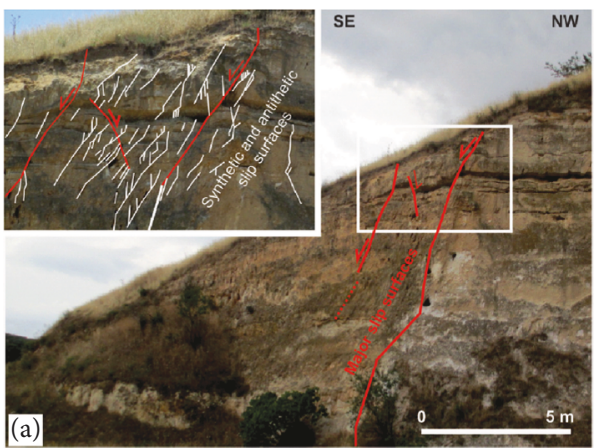

(a)

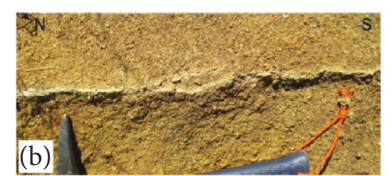

(b)

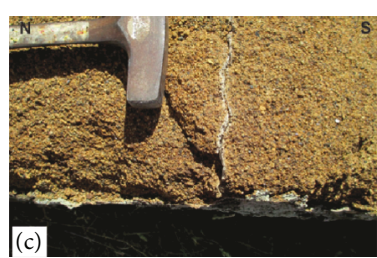

(c)

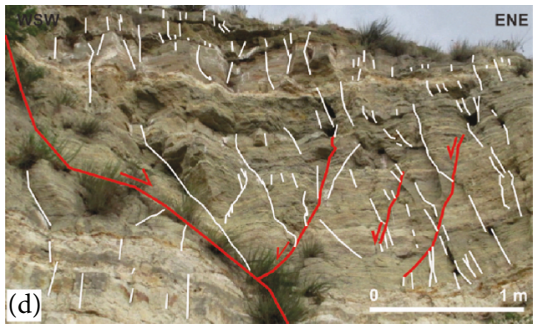

(d)

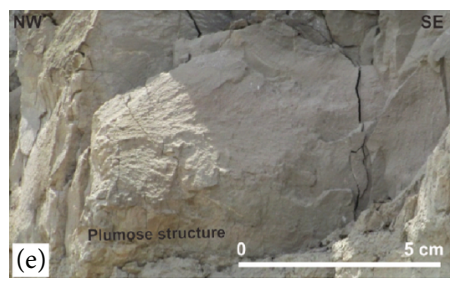

(e)

FIGURE 5: Main structural elements present along the NE-SE fault zone exposed at the Toppo D'Aguzzo quarry. (a) Cross-sectional view of the fault zone. Both synthetic and antithetic slip surfaces located at the hanging wall of the main slip surface are reported in the inset. (b) Subvertical N-S striking veins forming an eye structure. (c) High-angle E-W striking vein abutting against a N-S vein. (d) The pyroclastic rocks exposed within the footwall damage zone are crosscut by NE-SW striking fractures localized at the dilational quadrants of sheared parental slip surfaces. See text for further details. (e) Plumose structure displayed along a NW-SE joint.

4.3. Fluid Inclusion Analysis. Fluid inclusions hosted within quartz crystals were classified according to phase types at room temperature. All descriptions refer to fluid inclusion assemblages (FIAs), which were strictly defined as fluid inclusion vacuoles along the same growth zone in a single crystal or along a single healed fracture that formed at about the same time or during the same set of P-T conditions [42]. The observed inclusions occur as trails that crosscut the quartz crystals (Figures 9(a) and 9(b)) and were assigned to a probable secondary origin according to the criteria of Roedder [43] and Goldstein [44]. These are small in size $(<15 \mu \mathrm{m}$, most of them $<10 \mu \mathrm{m}$ ), and part of them shows an ellipsoidal morphology whereas the others have an irregular shape (Figures 9(a) and 9(b)). Two types of inclusions were identified in the examined samples by microscopic observation at room temperature: Type 1 two-phase (liquid + vapor) inclusions $(\mathrm{L}+\mathrm{V})$, liquid-rich at room temperature; Type 2 liquid only (L) inclusions.

Type $1(\mathrm{~L}+\mathrm{V})$ inclusions comprise about $80 \%$ of the fluid inclusion population. They are characterized by a scarce variability in the vapor/liquid ratio, with the vapor bubble that occupies around $10-20 \%$ of the total volume at room temperatures (Figure 9(a)). Vapor bubble often vibrates. Type 2 (L) inclusions mainly occur in the planar groups along variably healed fracture planes (Figure 9(b)). They are very small in size $(<5 \mu \mathrm{m}$ in diameter). Due to the small size of the inclusions, the petrographic relationships between the two populations of fluid inclusions are not clear; as a consequence, we cannot make an unequivocal interpretation of the timing of entrapment only based on microscopic observation at room temperature.

Microthermometric analyses were conducted on Type 1 $(\mathrm{L}+\mathrm{V})$ fluid inclusions. Results of this investigation are reported in Figure 9(c). Upon heating, total homogenization $\left(\mathrm{T}_{\mathrm{h}}\right)$ of these inclusions was observed through the disappearance of vapor in the liquid phase at temperatures ranging between 167 and $261^{\circ} \mathrm{C}$ with a mode around $200^{\circ} \mathrm{C}$ (Figure 9(c)). The small size of the inclusions hindered the observation of initial ice melting, and also final ice melting $\left(\mathrm{T}_{\mathrm{mi}}\right)$ was possible to be observed only in very few inclusions. The $\mathrm{T}_{\mathrm{mi}}$ values are around $-1.5^{\circ} \mathrm{C}$, corresponding to salinity of about $2.6 \mathrm{NaCl}$ wt.\% $\%_{\text {equiv. }}$ calculated according to Bodnar [45]. However, the scarce statistics does not allow having great confidence concerning this value of salinity.

\section{Discussion}

The results of integrated geological, structural, mineralogical, and fluid inclusion analyses of a hydrothermally altered highangle fault zone exposed in the vicinity of the Rapolla village, along the eastern flank of the Vulture volcano, are consistent with the occurrence of a relatively high-temperature, fossil, hydrothermal system whose temperature and composition varied with time. The alteration mineralogical paragenesis associated with the hydrothermal veins and fluid inclusion data suggest that the earliest fluids that circulated in the system (Stage 1) were characterized by temperature around $200^{\circ}-210^{\circ} \mathrm{C}$ and low- $\mathrm{pH}$ conditions $(\mathrm{pH}<4)$. Individual 


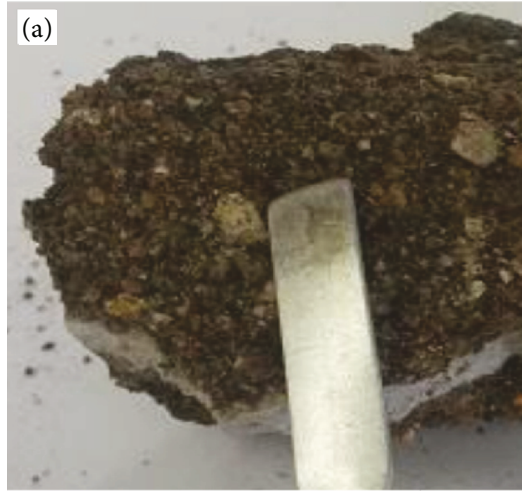

(a)

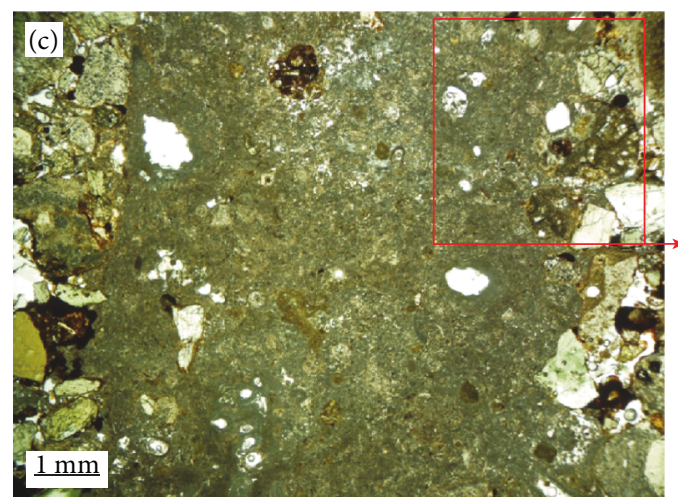

(c)

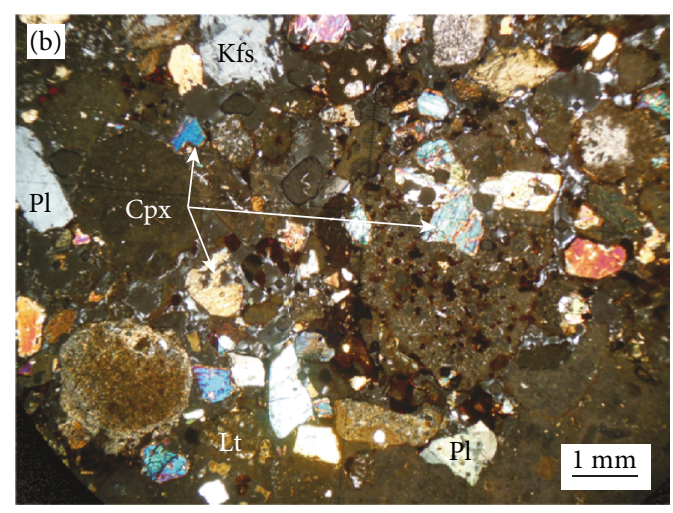

(b)

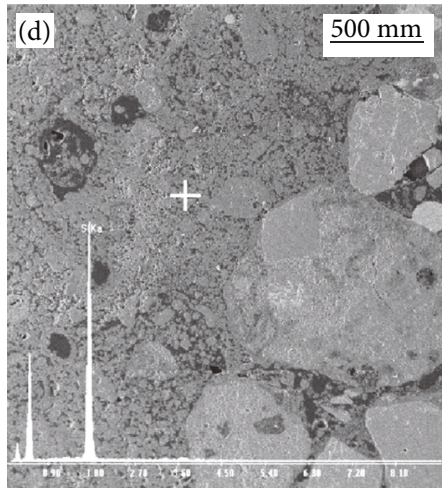

(d)

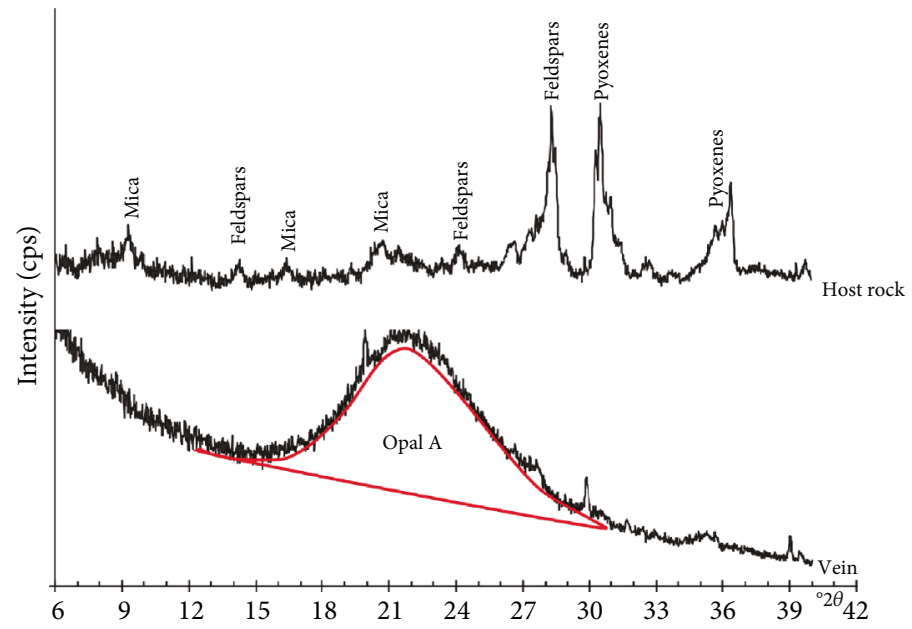

(e)

Figure 6: (a) Picture of representative sample (dark host rock and white vein); (b) OM observation of host rock. Kfs: k-feldspar; Cpx: clinopyroxene; Pl: plagioclase; Lt: lithic fragments. (c) OM observation vein; (d) SEM image and EDX spectra of opal; (e) XRD diffraction profiles of the host rock and vein.

hand specimens collected from the pyroclastics pertaining to the Foggianello synthem (cf. Sections 4.1 and 4.2) point out to the formation of an advanced argillic mineralogical assemblage. The alteration mineralogical assemblage is dominated by the alunite group minerals (mainly jarosite), which are stable under low- $\mathrm{pH}$ conditions $(\mathrm{pH}<4)$ and high- $\mathrm{SO}_{4}{ }^{2-}$ ion activity [46]. Jarosite also precipitated within the crossorthogonal N-S and E-W striking fracture sets, and in the fault-related NE-SW striking fracture. Development of this high-temperature hydrothermal system required that a significant thermal anomaly, able to efficiently supply heat to the overlying pyroclastic rocks, was established in the area at the time of jarosite precipitation. The heat source could be envisaged in a shallow magma chamber connected to the development of the Vulture volcano. The occurrence of a relatively shallow magma chamber during emplacement of the Fara d'Olivo ignimbrite, during the Middle Pleistocene, is strongly suggested by the fact that an impressive caldera 

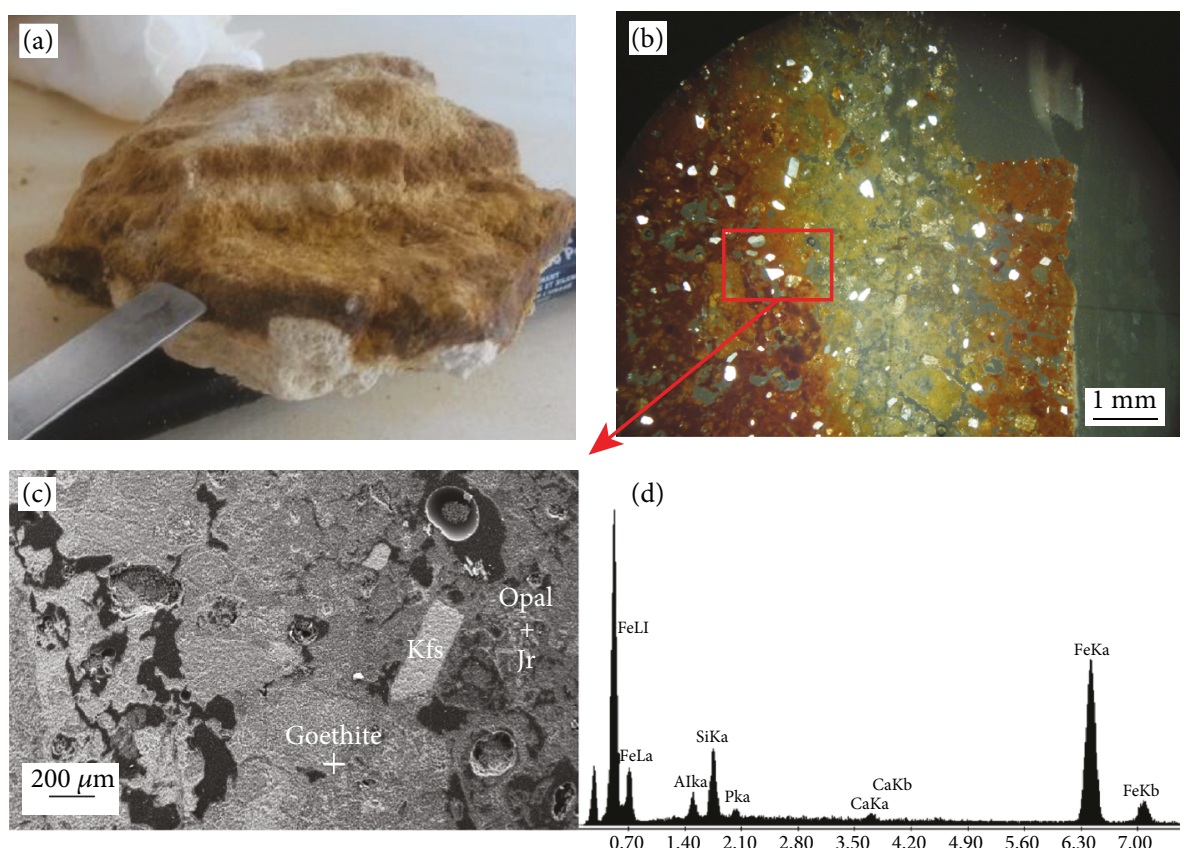

(d)

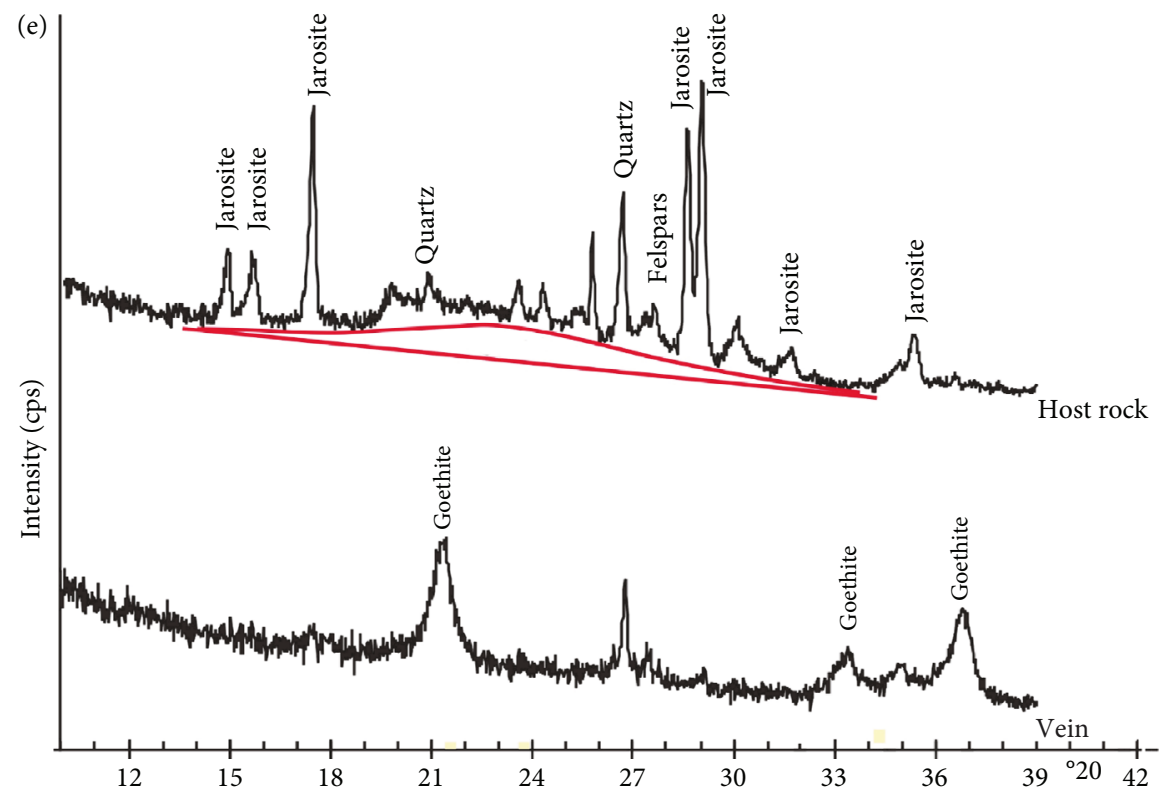

Figure 7: (a) Picture of the representative sample (yellow host rock and white vein); (b) OM observations (crossed polars); (c, d) SEM image and EDX spectra of goethite. Jr: jarosite; Qtz: quartz. (e) XRD diffraction profiles of the host rock and vein.

depression formed in response to the big explosive eruption that spread over a large area of ignimbritic deposits and emptied the magma chamber ([34] and references therein). It is known that calderas are the result of the collapse of rocks that overlies shallow magma chambers, which takes place after the sudden withdrawal of magma due to an explosive eruption $[47,48]$.

Both acidic conditions of the early hydrothermal fluids and the inferred high- $\mathrm{SO}_{4}{ }^{2-}$ ion activity were likely related to the input of deep $\mathrm{H}_{2} \mathrm{~S}$ from organic substances entrapped within the Apulian Platform and/or from degassing from the Vulture magma chamber. $\mathrm{H}_{2} \mathrm{~S}$ condensed in oxygenated hydrothermal fluids producing $\mathrm{H}_{2} \mathrm{SO}_{4}$ (equation 1), which lowered the $\mathrm{pH}$ conditions and gave rise to the advanced argillic mineralogical assemblage.

$$
\mathrm{H}_{2} \mathrm{~S}+2 \mathrm{O}_{2}=\mathrm{H}_{2} \mathrm{SO}_{4}
$$

A drop of temperature and acidity of the fluids, with opal A precipitation (Stage 2) both outside and within the NE-SW trending high-angle fault zone, followed the aforementioned high-temperature and low-pH hydrothermal activity stage (Stage 1). Outside the fault zone, within the volcaniclastic rocks of the Barile synthem, opal A precipitated within both N-S and E-W cross-orthogonal joint sets (cf. Figure 5). Differently, within the Fara d'Olivo pyroclastics of the 


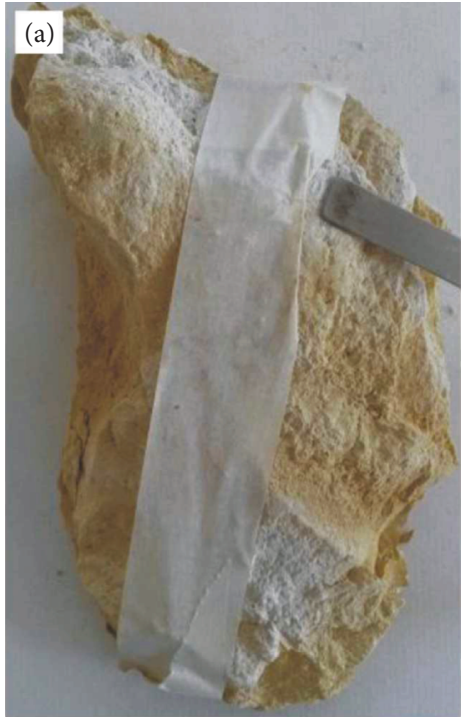

(a)

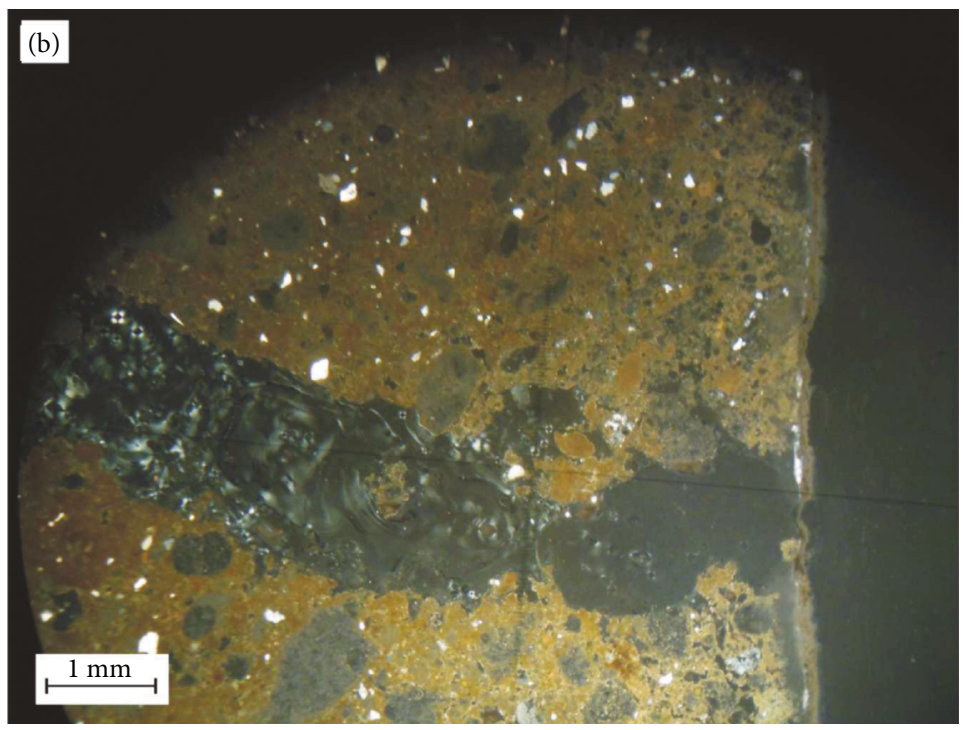

(b)

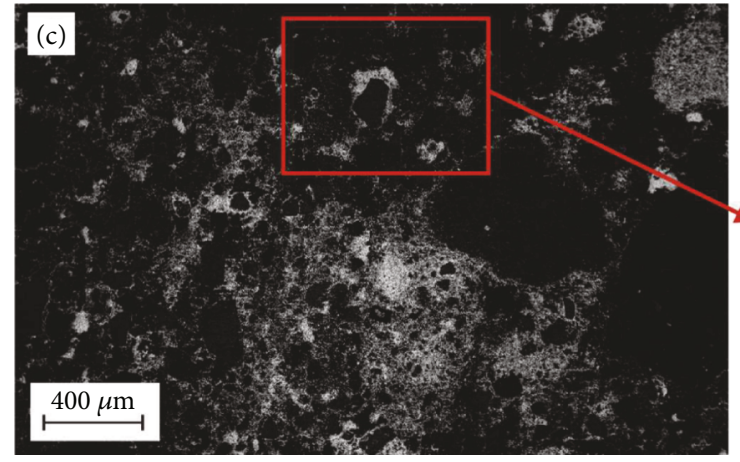

(c)

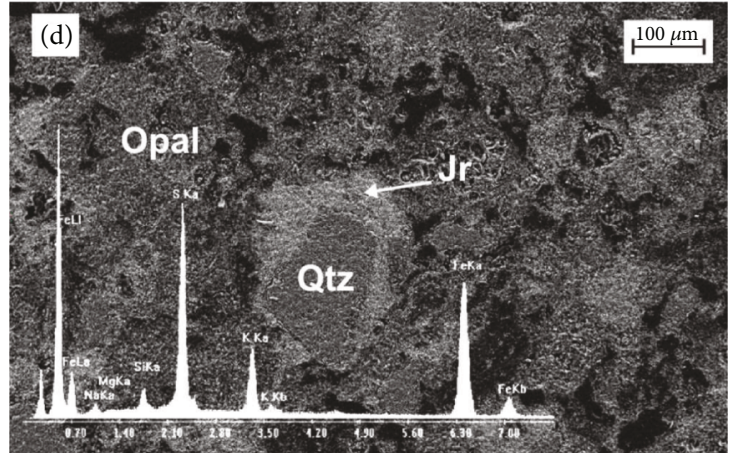

(d)

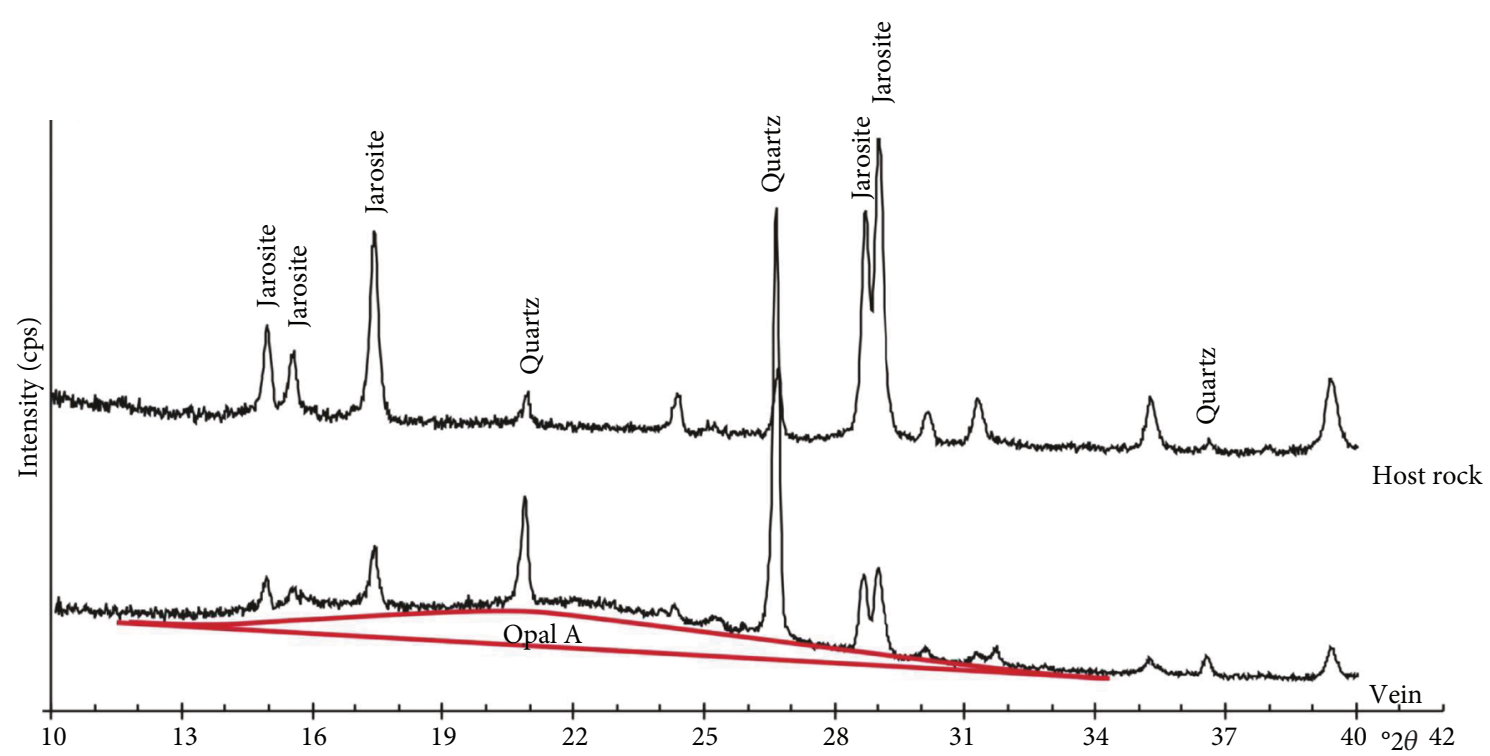

(e)

FIGURE 8: (a) Picture of representative sample (host rock white and brown vein); (b) OM observations; (d) SEM image and EDX spectra goethite. Jr: jarosite, Kfs: k-feldspar. (e) XRD diffraction profiles of the host rock and vein. 


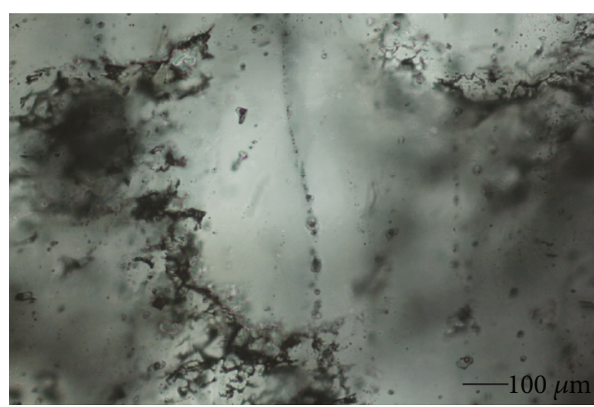

(a)

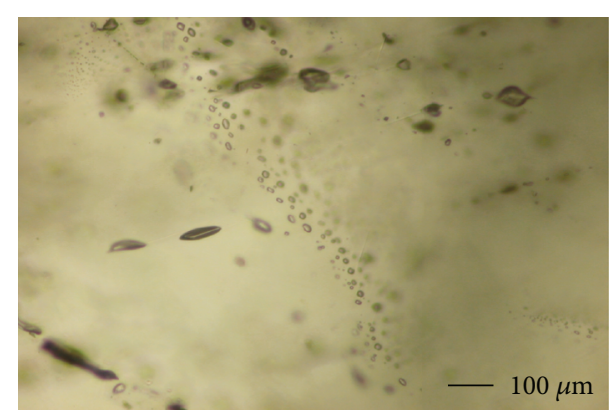

(b)

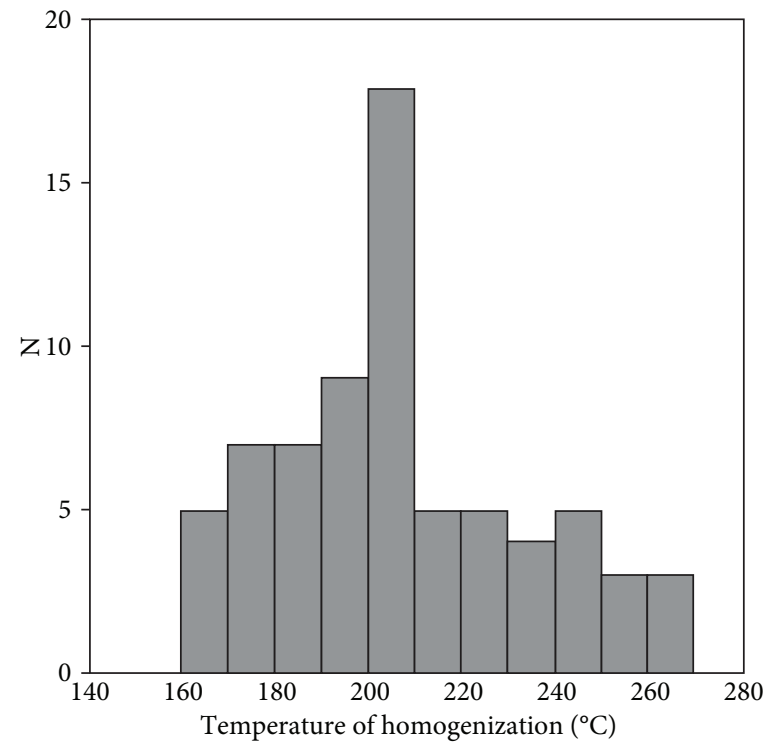

(c)

Figure 9: (a) Microphotograph of secondary trails of Type 1 two-phase liquid-rich $(\mathrm{L}+\mathrm{V})$ fluid inclusions; (b) microphotograph of secondary trails of Type 2 liquid only (L) fluid inclusions; (c) histogram of the homogenization temperatures of the studied Type 1 fluid inclusions. $N=$ number of measurements.

Foggianello synthem forming the footwall damage zone of the study fault zone, opal A precipitated within N-S, E-W, and NE-SW trending high-angle joints and sheared joints (cf. Figure 5). Opal A precipitated as a consequence of a drop of temperature of the hydrothermal fluids, which likely reduced the solubility of silica in solution. Hence, opal A precipitation during Stage 2 postdated crystallization of jarosite both within the fault-related joint and sheared joint sets (cf. Figure 5). We may hypothesize that the observed secondary fluid inclusion assemblage, which is made up of very small monophase inclusions (Type 2, Figure 9(b)), is representative of the hydrothermal fluids that circulated during Stage 2 and hence consistent with temperatures lower than $100^{\circ} \mathrm{C}$. If so, the drop of temperature that characterized the hydrothermal fluids between Stage 1 and Stage 2 is in the order of about $100^{\circ} \mathrm{C}$. Such a significant drop of temperature could be therefore related to the cooling of a shallow magma chamber of the Vulture volcano ([34] and references therein) and to the progressive deepening of the magma source [36] within an evolved, deeply rooted, NE-SW trending, high-angle transtensional fault zone [37].

The latest evolution of the aforementioned hydrothermal system was characterized by the goethite mineralization along the main slip surface (Stage 3 ). This mineralization partly developed as supergene alteration of jarosite and was related to the circulation of $\mathrm{CO}_{2}$-bearing meteoric water at low temperatures $\left(<30^{\circ} \mathrm{C}\right)$ through the main structural discontinuities under neutral to weakly acidic conditions $(\mathrm{pH}=6-7)$. Occurrence of travertine deposits in the Rapolla area [37] can represent the surficial expression of the circulation of these low-temperature fluids, which could be considered, to some extent, analogous to those present in the local Fe-rich aquifer of the Vulture volcano [49].

High-temperature hydrothermal systems in the frontal sector of recently active fold-and-thrust belts are rarely observed, because a low amount of heat flow characterizes these regions $[50,51]$. The particular conditions that led to the development of a high-temperature hydrothermal system in the Rapolla area, where the lithosphere thickness is around 90-100 km [28], must just be sought in the occurrence of the Vulture volcano, which formed in the frontal sector of the Apennines chain, not far from the western margin of the Apulia foreland. The origin of the Vulture volcano is related to the unusual mantle dynamic that has occurred after cessation of collision between the Adria-Africa and Europe plates [52]. This unusual feature allows considering the Rapolla 
area as a very rare case of a high-temperature hydrothermal system developed at the very front of an orogen.

Presently, the only evidence of a geothermal system in the area is represented by saline waters at temperatures of $35^{\circ} \mathrm{C}$ that have been discovered during drilling of some wells in the Bradano foredeep (Forestella and Montemilone wells) at a depth of about $600 \mathrm{~m}$ [53]. Waters circulate within a horst formed by fractured Cretaceous carbonates of the Apulian Platform, located about $15 \mathrm{~km}$ East of the study area, sealed by Pleistocene clay. This finding, together with the heat flux anomaly reported for the Vulture area [6], point out the possible presence of a low- to medium-enthalpy geothermal system.

\section{Conclusions}

The results of this integrated geostructural, mineralogical, and fluid inclusion study take in evidences that hightemperature (ca. $200-210^{\circ} \mathrm{C}$ ) hydrothermal circulation occurred at quite shallow depths during burial diagenesis of pyroclasts pertaining to the Middle Pleistocene Foggianello and Barile synthems, Vulture volcano, southern Italy. There, at the outermost edge of the southern Apennine $\mathrm{ftb}$, the hydrothermal system was due to a short-time living, high positive thermal anomaly that localized along the eastern flanks of the Vulture volcano. Three main stages of activity of the hydrothermal system were documented. Stage 1 produced the circulation of fluids having low- $\mathrm{pH}$ conditions $(\mathrm{pH}<3-4)$ and relatively high- $\mathrm{SO}_{4}{ }^{2-}$ activity, as testified by the main hydrothermal mineralogical assemblage formed by jarosite and minor silica, typical of advanced argillic alteration facies. Hydrothermal fluids were characterized by high temperature around $200^{\circ}-210^{\circ} \mathrm{C}$. These hot fluids altered and mineralized the matrices of pyroclastic rocks and sealed both burial-related (N-S and E-W striking) and fault-related (NESW striking) fracture networks. Later hydrothermal circulation (Stage 2) was recorded by opal A-rich veins, which are present both inside and outside the transtensional fault zone. The fluids responsible of the second stage of development of the Rapolla area hydrothermal system were characterized by temperature conditions probably lower than $100^{\circ} \mathrm{C}$. Currently, goethite mineralization occurs along the main slip surfaces of the study high-angle fault zone, which is due to the circulation of meteoric-derived fluids pertaining to the local aquifer. This study highlights that a high-temperature hydrothermal system developed in the past in the Rapolla area within the transtensional fault zone, when a high thermal anomaly was present. If we take into account that this area is still affected by a heat flux positive anomaly $\left(90 \mathrm{~mW} / \mathrm{m}^{2}\right)$, we may infer that it has the potentiality to be considered an interesting site for future exploration devoted to the finding of medium-enthalpy geothermal resources at depth.

\section{Data Availability}

The data used to support the findings of this study are available from the corresponding author upon request.

\section{Conflicts of Interest}

The authors declare that they have no conflicts of interest.

\section{Acknowledgments}

The present work was supported by the Italian Ministry of Education and Research (RIL 2015-2017 grants to FA and GP), the Reservoir Characterization Project (FA and AVP), and the University of Pisa "Fondi d'Ateneo 2017" MIUR (PF). Alessandro Laurita (Microscopy Laboratory-University of Basilicata) is kindly acknowledged for his assistance in the SEM investigations. The authors also acknowledge the contribution of Francesco Colucci during the field and laboratory analyses.

\section{References}

[1] D. L. Norton, "Theory of hydrothermal systems," Annual Review of Earth and Planetary Sciences, vol. 12, no. 1, pp. 155-177, 1984.

[2] F. Pirajno, Hydrothermal Mineral Deposits. Principles and Fundamental Concepts for the Exploration Geologist, Springer-Verlag, Berlin, Heidelberg, 1992.

[3] S. Bellani, A. Brogi, A. Lazzarotto, D. Liotta, and G. Ranalli, "Heat flow, deep temperatures and extensional structures in the Larderello geothermal field (Italy): constraints on geothermal fluid flow," Journal of Volcanology and Geothermal Research, vol. 132, no. 1, pp. 15-29, 2004.

[4] J. P. Brun, M. A. Gutscher, and dekorp-ecors teams, "Deep crustal structure of the Rhine Graben from DEKORPECORS seismic reflection data: a summary," Tectonophysics, vol. 208, no. 1-3, pp. 139-147, 1992.

[5] I. Lucchitta, "Role of heat and detachment in continental extension as viewed from the eastern Basin and Range Province in Arizona," Tectonophysics, vol. 174, no. 1-2, pp. 77114, 1990.

[6] R. Cataldi, F. Mongelli, P. Squarci, L. Taffi, G. Zito, and C. Calore, "Geothermal ranking of Italian territory," Geothermics, vol. 24, no. 1, pp. 115-129, 1995.

[7] L. Beccaluva, M. Coltorti, P. Di Girolamo et al., "Petrogenesis and evolution of Mt. Vulture alkaline volcanism (southern Italy)," Mineralogy and Petrology, vol. 74, no. 2-4, pp. 277297, 2002.

[8] A. Brogi and P. Fulignati, "Tectonic control on hydrothermal circulation and fluid evolution in the Pietratonda-Poggio Peloso (southern Tuscany, Italy) carbonate-hosted Sb-mineralization," Ore Geology Reviews, vol. 44, pp. 158-171, 2012.

[9] A. Brogi, L. Fabbrini, and D. Liotta, "Sb-Hg ore deposit distribution controlled by brittle structures: the case of the Selvena mining district (Monte Amiata, Tuscany, Italy)," Ore Geology Reviews, vol. 41, no. 1, pp. 35-48, 2011.

[10] M. Gasparrini, G. Ruggieri, and A. Brogi, "Diagenesis versus hydrothermalism and fluid-rock interaction within the Tuscan Nappe of the Monte Amiata $\mathrm{CO}_{2}$-rich geothermal area (Italy)," Geofluids, vol. 13, no. 2, 179 pages, 2013.

[11] D. Liotta, G. Ruggieri, A. Brogi, P. Fulignati, A. Dini, and I. Nardini, "Migration of geothermal fluids in extensional terrains: the ore deposits of the Boccheggiano-Montieri area (southern Tuscany, Italy)," International Journal of Earth Sciences, vol. 99, no. 3, pp. 623-644, 2010. 
[12] D. Liotta, A. Brogi, M. Meccheri, A. Dini, C. Bianco, and G. Ruggieri, "Coexistence of low-angle normal and highangle strike- to oblique-slip faults during Late Miocene mineralization in eastern Elba Island (Italy)," Tectonophysics, vol. 660, pp. 17-34, 2015.

[13] E. Patacca and P. Scandone, "The 1627 Gargano earthquake (southern Italy): identification and characterization of the causative fault," Journal of Seismology, vol. 8, no. 2, pp. 259273, 2004.

[14] M. Boccaletti, F. Calamita, G. Deiana et al., "Migrating foredeep-thrust belt systems in the northern Apennines and southern Alps," Palaeogeography, Palaeoclimatology, Palaeoecology, vol. 77, no. 1, pp. 3-14, 1990.

[15] P. Casero, F. Roure, I. Moretti, L. Sage, and R. Vially, "Evoluzione geodinamica neogenica dell'Appennino meridionale," Memorie della Societa Geologica Italiana, vol. 41, pp. 109120, 1988.

[16] E. Patacca and P. Scandone, "Post-Tortonian mountain building in the Apennines. The role of the passive sinking of a relic lithosferical slab," in The Lithosphere in Italy: Advances in Earth Science Research : a Mid-term Conference Convened by the Italian National Committee for the International Lithosphere Program, Volume 80 of Atti dei convegni Lincei, A. Boriani, M. Bonafede, G. B. Piccardo, and G. B. Vai, Eds., pp. 157176, Accademia Nazionale dei Lincei, 1989.

[17] E. Patacca and P. Scandone, "Late trust propagation and sedimentary response in the thrust belt-foredeep system of the southern Apennines (Pliocene-Pleistocene)," in Anatomy of an Orogen: The Apennines and Adjacent Mediterranean Basins, G. B. Vai and I. P. Martini, Eds., pp. 401-440, Kluwer Academic Publishers, Great Britain, 2001.

[18] E. Patacca, R. Sartori, and P. Scandone, "Tyrrhenian basin and Apenninic arcs: kinematic relations since late Tortonian times," Memorie della Societa Geologica Italiana, vol. 45, pp. 425-451, 1990.

[19] S. Piedilato and G. Prosser, "Thrust sequences and evolution of the external sector of a fold and thrust belt: an example from the southern Apennines (Italy)," Journal of Geodynamics, vol. 39, no. 4, pp. 386-402, 2005.

[20] V. Del Gaudio, P. Pierri, A. Frepoli, G. Calcagnile, N. Venisti, and G. B. Cimini, "A critical revision of the seismicity of Northern Apulia (Adriatic microplate - Southern Italy) and implicationsfor the identification of seismogenic structures," Tectonophysics, vol. 436, no. 1-4, pp. 9-35, 2007.

[21] P. Favali, G. Mele, and G. Mattietti, "Contribution to the study of the Apulian microplate geodynamics," Memorie della Societa Geologica Italiana, vol. 44, pp. 71-80, 1990.

[22] I. Korneva, E. Tondi, F. Agosta et al., "Structural properties of fractured and faulted Cretaceous platform carbonates, Murge plateau (southern Italy)," Marine and Petroleum Geology, vol. 57, pp. 312-326, 2014.

[23] V. La Bruna, F. Agosta, J. Lamarche, S. Viseur, and G. Prosser, "Fault growth mechanisms and scaling properties in foreland basin system: the case study of Monte Alpi, southern Apennines, Italy," Journal of Structural Geology, vol. 116, pp. 94113, 2018.

[24] A. V. Petrullo, F. Agosta, G. Prosser, and E. Rizzo, "Cenozoic tectonic evolution of the northern Apulian carbonate platform (southern Italy)," Italian Journal of Geosciences, vol. 136, no. 2, pp. 296-311, 2017.

[25] M. Sella, C. Turci, and A. Riva, "Petroleum geology of the 'Fossa Bradanica' (foredeep of the southern Apennine thrust belt)," in Classic Petroleum Provinces, J. Brooks, Ed., vol. 50, no. 1pp. 369-378, Geological Society of London Special Publications, 1990.

[26] N. Ciaranfi, P. Pieri, and G. Ricchetti, "Note alla carta geologica delle Murge e del Salento (Puglia centromeridionale)," Memorie della Societa Geologica Italiana, vol. 41, pp. 449460, 1992.

[27] C. Doglioni, F. Mongelli, and P. Pieri, “The Puglia uplift (SE Italy): an anomaly in the foreland of the Apenninic subduction due to buckling of a thick continental lithosphere," Tectonics, vol. 13, no. 5, pp. 1309-1321, 1994.

[28] C. Doglioni, P. Harabaglia, G. Martinelli, F. Mongelli, and G. Zito, "A geodynamic model of the southern Apennines accretionary prism," Terra Nova, vol. 8, no. 6, pp. 540-547, 1996.

[29] C. Doglioni, F. Innocenti, and G. Mariotti, "Why Mt. Etna?, Terra Nova, vol. 13, no. 1, pp. 25-31, 2001.

[30] J. E. Guest, A. M. Duncan, and D. K. Chester, "Monte Vulture volcano (Basilicata, Italy): an analysis of morphology and volcaniclastic facies," Bulletin of Volcanology, vol. 50, no. 4, pp. 244-257, 1988.

[31] L. La Volpe and C. Principe, "Comments on "Monte Vulture Volcano (Basilicata, Italy): an analysis of morphology and volcaniclastic facies" by J. E. Guest, A. M. Duncan and D. K. Chester," Bulletin of Volcanology, vol. 53, no. 3, pp. 222-227, 1991.

[32] F. Stoppa and C. Principe, "Erratum to "Eruption style and petrology of a new carbonatitic suite from the Mt. Vulture Southern Italy: the Monticchio Lakes formation", Journal of Volcanology and Geothermal Research, vol. 78, pp. 251-265, 1998.

[33] D. Scrocca, C. Doglioni, and F. Innocenti, "Contraints for an interpretation of the Italian geodynamics: a review," Memorie Descrittive della Carta Geologica d'Italia, vol. 62, pp. 15-46, 2003.

[34] P. Giannandrea, L. La Volpe, C. Principe, and M. Schiattarella, "Unità stratigrafiche a limiti inconformi e storia evolutiva del volcano medio-pleistocenico di Monte Vulture (Appennino meridionale, Italia)," Bollettino - Societa Geologica Italiana, vol. 125, pp. 67-92, 2006.

[35] P. Beneduce and S. I. Giano, "Osservazioni preliminari sull'assetto morfostrutturale dell'edificio vulcanico del Monte vulture (Basilicata)," Il Quaternario Italian Journal of Quaternary Sciences, vol. 9, pp. 325-330, 1996.

[36] M. Schiattarella, P. Beneduce, P. Di Leo, S. I. Giano, P. Giannandrea, and C. Principe, "Assetto strutturale ed evoluzione morfotettonica quaternaria del vulcano del Monte Vulture (Appennino lucano)," Bollettino- Societa Geologica Italiana, vol. 124, pp. 543-562, 2005.

[37] R. Sinisi, A. V. Petrullo, F. Agosta, M. Paternoster, C. Belviso, and F. Grassa, "Contrasting fault fluids along high-angle faults: a case study from southern Apennines (Italy)," Tectonophysics, vol. 690, pp. 206-218, 2016.

[38] P. Montone, M. T. Mariucci, S. Pondrelli, and A. Amato, “An improved stress map for Italy and surrounding regions (Central Mediterranean)," Journal of Geophysical Research, vol. 109, no. B10, 2004.

[39] F. Agosta, P. Ruano, A. Rustichelli, E. Tondi, J. Galindo-Zaldívar, and C. Sanz de Galdeano, "Inner structure and deformation mechanisms of normal faults in conglomerates and carbonate grainstones (Granada Basin, Betic cordillera, Spain): 
inferences on fault permeability," Journal of Structural Geology, vol. 45, pp. 4-20, 2012.

[40] F. Agosta, C. Wilson, and A. Aydin, "The role of mechanical stratigraphy on normal fault growth across a cretaceous carbonate multi-layer, Central Texas (USA)," Italian Journal of Geosciences, vol. 134, no. 3, pp. 423-441, 2015.

[41] N. C. Davatzes and A. Aydin, "The formation of conjugate normal fault systems in folded sandstone by sequential jointing and shearing, Waterpocket monocline, Utah," Journal of Geophysical Research, vol. 108, no. B10, 2003.

[42] R. H. Goldstein and T. J. Reynolds, "Systematics of fluid inclusions in diagenetic minerals," Society for Sedimentary Geology Short Course, vol. 31, pp. 1-199, 1994.

[43] E. Roedder, "Fluid inclusions," Reviews in Mineralogy, vol. 12, pp. 1-644, 1984.

[44] R. H. Goldstein, "Petrographic analysis of fluid inclusions," in Fluid Inclusions Analysis and Interpretation, I. Samson, A. Anderson, and D. Marshall, Eds., vol. 32, pp. 9-53, Mineralogical Association of Canada, Short Course, 2003.

[45] R. J. Bodnar, "Revised equation and table for determining the freezing point depression of $\mathrm{H}_{2} \mathrm{O}-\mathrm{NaCl}$ solutions," Geochimica et Cosmochimica Acta, vol. 57, no. 3, pp. 683-684, 1993.

[46] R. E. Stoffregen, "Genesis of acid-sulfate alteration and $\mathrm{Au}-\mathrm{Cu}$ Ag mineralization at Summitville, Colorado," Economic Geology, vol. 82, no. 6, pp. 1575-1591, 1987.

[47] M. Branney and V. Acocella, "Chapter 16 - Calderas," in Encyclopedia of Volcanoes, H. Sigurdsson, Ed., 299-315, 2015.

[48] K. Wohletz and G. Heiken, Volcanology and Geothermal Energy, University Of California Press Berkeley, 1992.

[49] M. Paternoster, S. Parisi, A. Caracausi, R. Favara, and G. Mongelli, "Groundwaters of Mt. Vulture volcano, southern Italy: chemistry and sulfur isotope composition of dissolved sulfate," Geochemical Journal, vol. 44, no. 2, pp. 125-135, 2010.

[50] N. McQuarrie and T. A. Ehlers, "Techniques for understanding fold-and-thrust belt kinematics and thermal evolution," in Linkages and feedbacks in orogenic systems, R. D. Law, J. R. Thigpen, A. J. Mershat, and H. D. Stowell, Eds., vol. 213, pp. 25-54, Geological Society of America, 2017.

[51] H. N. Pollack, S. J. Hurter, and J. R. Johnson, "Heat flow from the Earth's interior: analysis of the global data set," Reviews of Geophysics, vol. 31, no. 3, pp. 267-280, 1993.

[52] G. De Astis, P. D. Kempton, A. Peccerillo, and T. W. Wu, "Trace element and isotopic variations from Mt. Vulture to Campanian volcanoes: constraints for slab detachment and mantle inflow beneath southern Italy," Contributions to Mineralogy and Petrology, vol. 151, no. 3, pp. 331-351, 2006.

[53] G. Tamburriello, M. Balasco, E. Rizzo, P. Harabaglia, V. Lapenna, and A. Siniscalchi, "Deep electrical resistivity tomography and geothermal analysis of Bradano foredeep deposits in Venosa area (Southern Italy): preliminary results," Annals of Gephysics, vol. 51, no. 1, 2008.

[54] P. Giannandrea, L. La Volpe, C. Principe, and M. Schiattarella, "Carta Geologica del Monte Vulture alla scala 1:25.000," in Litografia Artistica Cartografica, Firenze, 2004. 

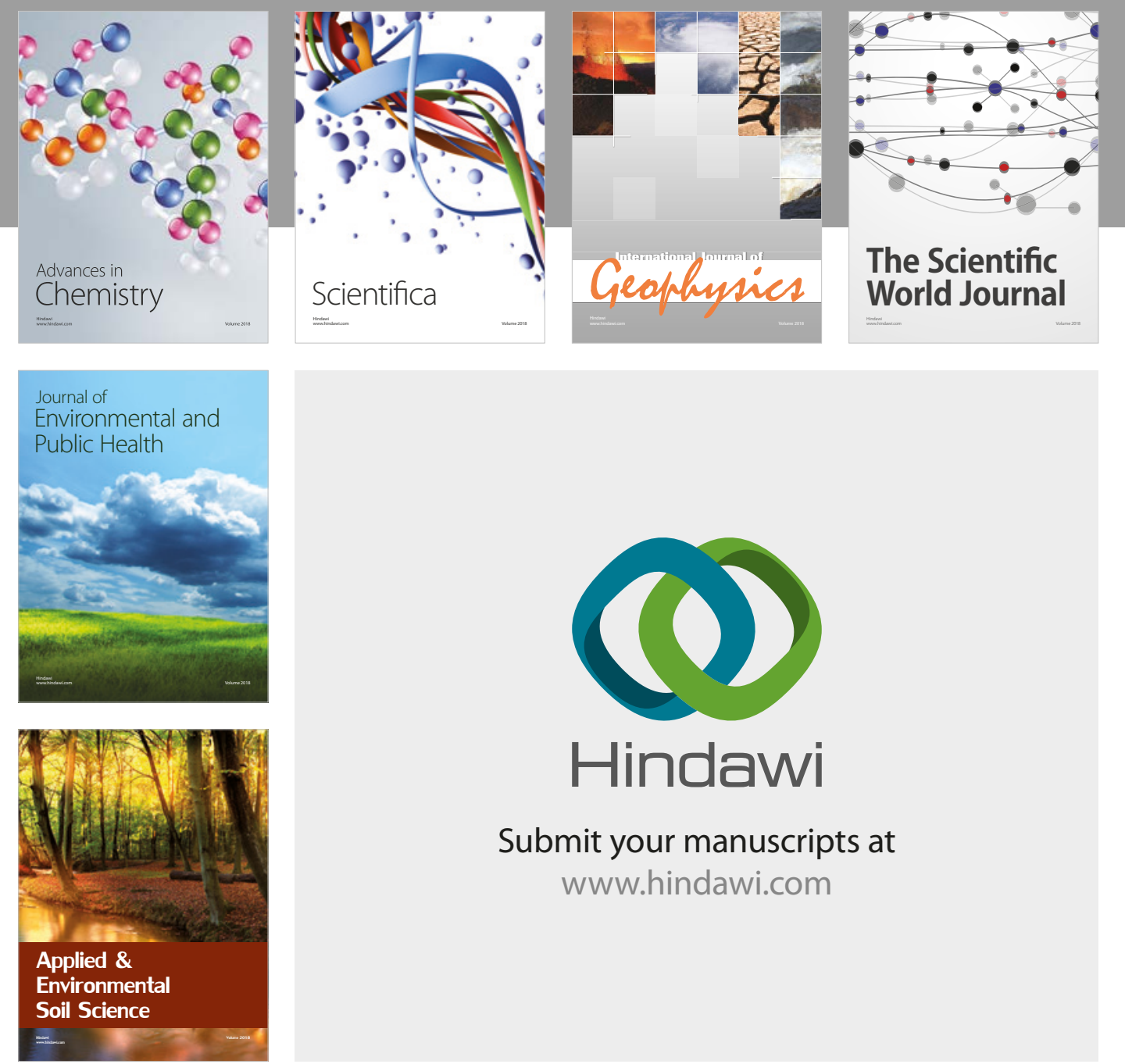

The Scientific

\section{World Journal}
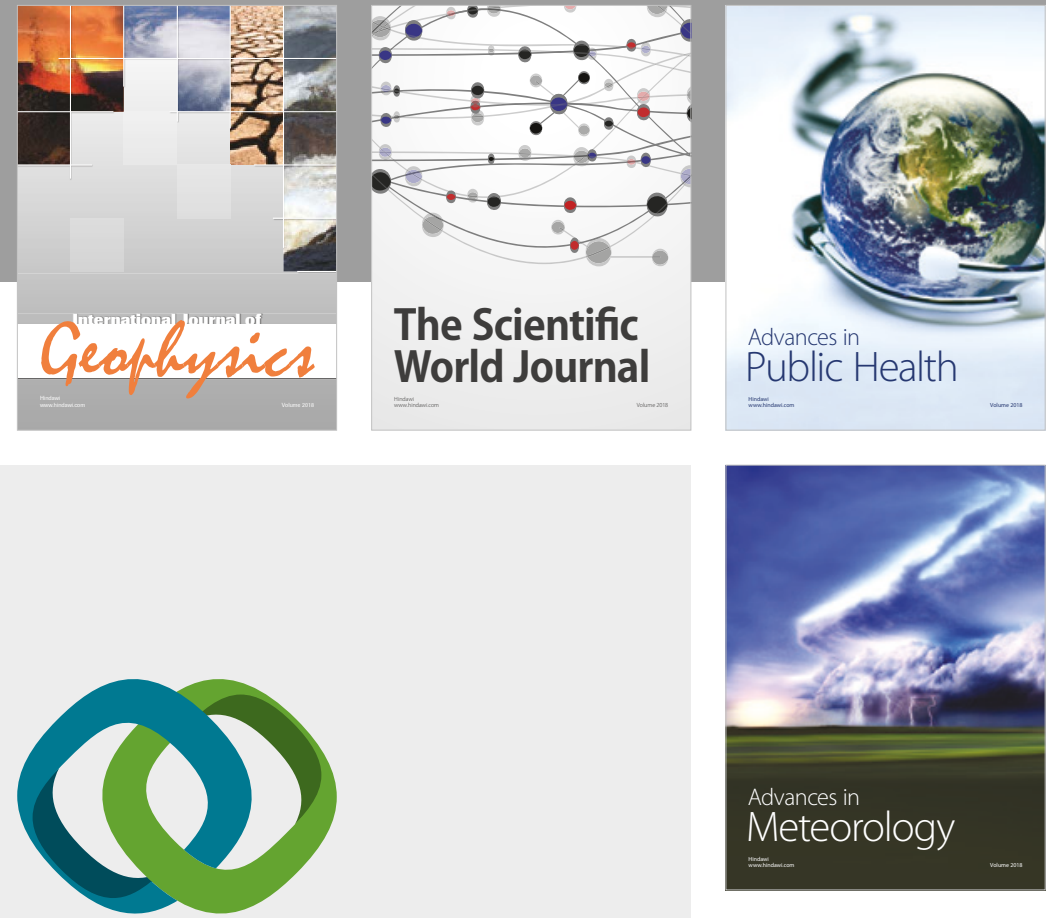

Advan

Public Health

\section{Hindawi}

Submit your manuscripts at

www.hindawi.com
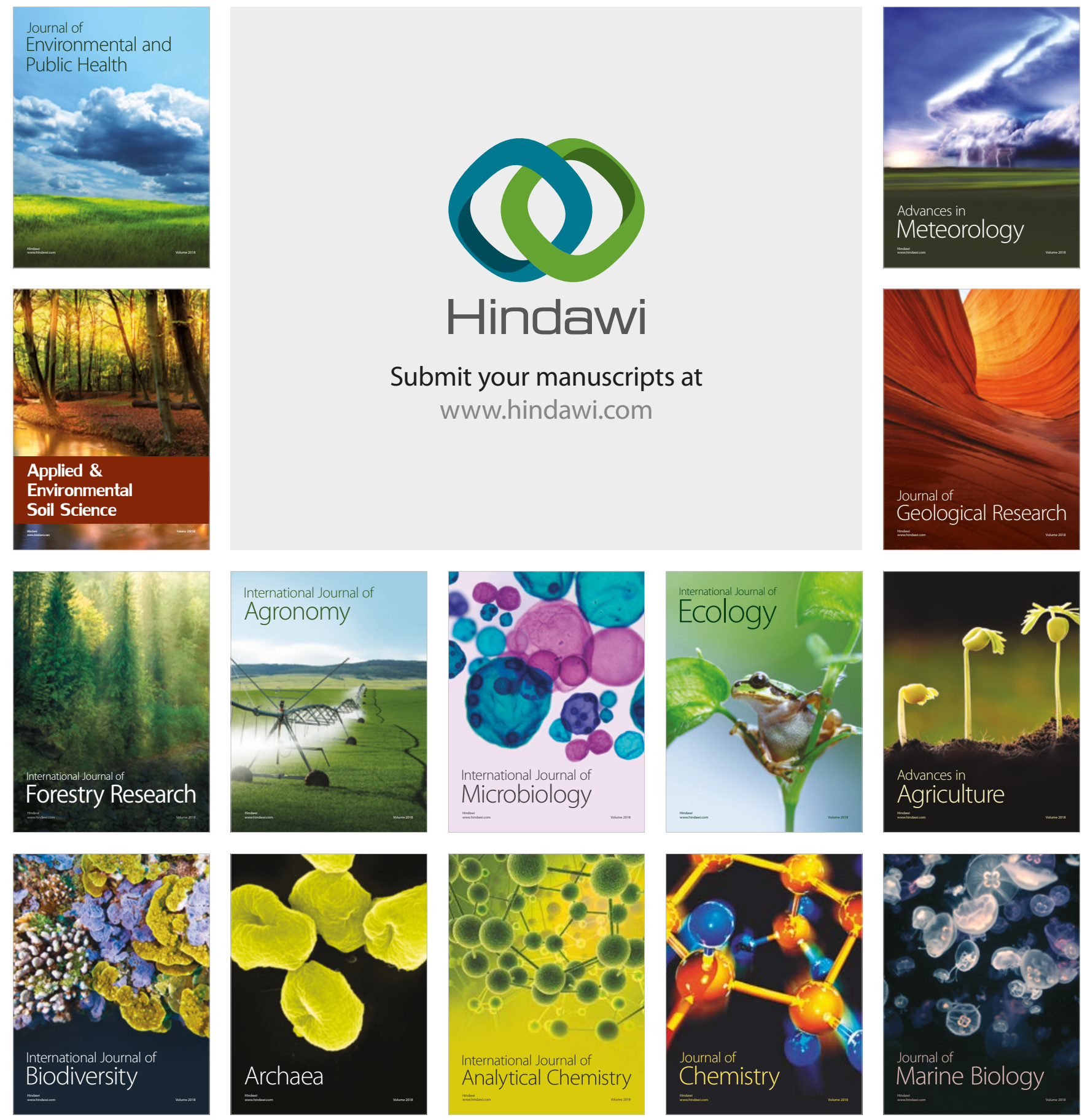